\title{
Yükseköğretimde Kalite İçin Meslek Yüksekokulu Öğrencilerinin Görüşleri ${ }^{*}$
}

\section{Opinions of Vocational College Students for Quality in Higher Education}

\author{
Ertuğ Can ${ }^{\mathrm{a}, * *}$ \\ ${ }^{a}$ Doç. Dr., Kırklareli Üniversitesi, Fen Edebiyat Fakültesi, Eğitim Bilimleri Bölümü, 39000 Kırklareli/Türkiye. \\ ORCID: 0000-0002-0885-9042
}

\section{MAKALE BİLGISI}

\section{Makale Geçmişi:}

Başvuru tarihi: 10 Ekim 2019

Düzeltme tarihi: 21 Kasım 2019

Kabul tarihi: 18 Aralık 2019

\author{
Anahtar Kelimeler: \\ Eğitimde kalite \\ Meslek yüksekokulları \\ Yükseköğretimde kalite \\ Meslekî eğitim
}

\section{ARTICLE INFO}

\section{Article history:}

Received 10 October 2019

Received in revised form 21 November 2019

Accepted 18 December 2019

\section{Keywords:}

Quality in education

Vocational colleges

Quality in higher education

Vocational education

\section{ÖZ}

$\mathrm{Bu}$ araştırmanın amacı, meslek yüksekokullarında kalite için ihtiyaçları belirlemek ve öneriler geliştirmektir. Araştırmada nitel araştırma yöntemi kullanılmıştır. Araştırma 2017-2018 eğitimöğretim yılında Kırklareli Üniversitesi’nin yedi farklı meslek yüksekokulunda gerçekleştirilmiştir. Araştırmanın verileri, yapılandırılmış bir açık uçlu soru ile 120 öğrenciden toplanmış ve içerik analizi ile değerlendirilmiştir. Araştırma bulgularına göre, meslek yüksekokullarında kalitenin sağlanabilmesi için öğrenci memnuniyeti, beklenti ve ihtiyaçlarının karşılanması gerekmektedir. Öğrencilere göre, teorik eğitimden daha çok, uygulamalı eğitime önem verilmelidir. Ayrıca, öğrencilere göre meslek yüksekokullarının fiziksel ve teknolojik olanakları arttırılmalı, daha fazla bütçe ayrılmalı, öğrencilerle etkili iletişim kurulmalı, sosyal, bilimsel ve sportif etkinliklere önem verilmelidir. Meslek yüksekokullarındaki eğitimin kalitesi aynı zamanda yükseköğretim sistemindeki kaliteye olumlu katkılar sağlayabilir. Bu nedenle, yükseköğretimde meslekî ve teknik eğitim için kalite odaklı bir politika uygulanmalıdır.

\begin{abstract}
A B S T R A C T
The purpose of this research is to determine the needs for quality in vocational colleges and to develop suggestions. Qualitative research method was used in the research. The research was conducted in seven different vocational schools of Kurklareli University in 2017-2018 academic year. The data of the research were collected from 120 students with a structured open-ended question and evaluated by content analysis. According to the findings of the research, students' satisfaction, expectations and needs must be met in order to ensure quality in vocational colleges. According to the students, practical education should be given more importance than theoretical education. In addition, according to students, physical and technological opportunities of vocational colleges should be increased, more budget should be allocated, effective communication should be established with students and social, scientific and sportive activities should be given importance. The quality of education in vocational colleges can also contribute positively to the quality of the higher education system. Therefore, a quality-oriented policy should be implemented for vocational and technical education in higher education.
\end{abstract}

\section{Giriş}

2547 sayılı kanunla kurulmuş olan meslek yüksekokulları, belli mesleklere ara insan gücü yetiştiren, 2 yıl (4 yarı yıl) süreli eğitim öğretim hizmeti sunan yükseköğretim kurumlarıdır. Yükseköğretim istatistiklerine göre (YÖK, 2019), Türkiye'de 2018-2019 öğretim yılı itibariyle 129'u Devlet, 73'ü Vakıf ve 5'i Vakıf Meslek Yüksekokulu olmak üzere, toplam 207 yükseköğretim kurumu bulunmaktadır. Mevcut yükseköğretim kurumları içinde ise, 891'i Devlet,

\footnotetext{
"Bu araştırma, 3-5 Nisan 2019 tarihleri arasında, Gazi Üniversitesi tarafindan Ankara'da düzenlenen, The International Virtual Symposium of Innovations in Education and Social Sciences (IVSESS 2019)' da, 'Yükseköğretimde Kalite: Meslek Yüksekokulları İçin Öneriler" başlıklı sözlü bildiri olarak sunulmuş, ayrıca geliştirilmiş ve güncellenmiştir.

** Sorumlu yazar/Corresponding author

e-posta: ertugcan@gmail.com
} 
106'sı Vakıf ve 5'i Vakıf Meslek Yüksekokulu olmak üzere toplam 1.002 Meslek Yüksekokulu öğretim hizmeti vermektedir. Yükseköğretimde öğrenim gören 7.740 .502 öğrencinin 2.829.430’u (yaklaşık \%37) önlisans programlarında öğrenim görmektedir. Önlisans programlarına kayıtlı öğrencilerin $\% 95{ }^{\prime} \mathrm{i}$ ise Devlet Üniversitelerine bağlı Meslek Yüksekokullarında öğrenim görmektedir.

2018-2019 öğretim yılı verilerine (YÖK, 2019) göre, Meslek Yüksekokullarında toplam 22.725 öğretim elemanı görev yapmaktadır. Öğretim elemanlarının unvan dağılımı incelendiğinde, 465'i Profesör, 482'si Doçent, 3.861'i Dr.Öğr.Üyesi, 17.679'u Öğretim Görevlisi, 238'i ise Araştırma Görevlisidir. Görüldüğü gibi, Meslek Yüksekokullarında görevli öğretim elemanlarının büyük bir çoğunluğu (\%78), Öğretim Görevlisidir. Bu sayısal veriler, Türkiye'de Meslek Yüksekokullarının yükseköğretimdeki önemini sayısal olarak ortaya koymaktadır. Ancak, sayısal bakımdan yükseköğretimde bu kadar önemli bir yeri olan Meslek Yüksekokullarının, eğitimin kalitesi bakımından da incelenmesi ihtiyacı bulunmaktadır.

Dünyada yükseköğretim kurumları ve öğrenci sayılarında belirgin artışlar başlayınca ve büyüyen yükseköğretim sisteminin finansmanında sıkıntılar baş gösterince, karar alıcılar kalite güvencesine daha fazla önem vermeye başlamışlardır (Özer, Gür ve Küçükcan, 2010, s.11). Yükseköğretimde kademeli olarak ortaya çıkan hizmet kalitesi (Tan \& Simpson, 2008), son yirmi yılda ilgi uyandırmış (Jelena, 2010) ve Elmas'ın (2012)'da belirttiği gibi, yükseköğretim kurumları için kalite konusu giderek önem kazanmaya başlamıştır. Owlia \& Aspinwall (1996, s.19), yükseköğretimde kalite unsurlarını bazı alt başlıklara göre sınıflandırmakta ve eğitimin kalitesinin başta öğrenciler olmak üzere, akademik personel ve çalışanlar açısından da büyük önem taşıdığını vurgulamaktadır. Yükseköğretimdeki kalite unsurlarından bazılarını ise, yeterli ve modern donanım ve tesisler, güzel çevre, ulaşım kolaylığg, destek hizmetler (barınma, spor, sosyal hizmetler), akademik personelin niteliği, öğrencilerin ihtiyaçlarının anlaşılması, programların öğrencilerin ihtiyaçlarına uygunluğu, hizmetlerin sunumu, öğrenci geribildirimlerinin değerlendirilmesi, güvenilirlik ve problemlerin çözülmesi şeklinde sıralamaktadır. Yavuz ve Gülmez'e (2016) göre, yükseköğretim kurumlarında hizmet kalitesinin iyileştirilebilmesi için, öğrenci sayısı ile öğretim elemanı arasında denge sağlanması, özellikle yeni kurulan üniversitelerin akademik ve fiziksel yönden geliştirilmesi, öğrenci görüşlerine önem verilmesi, verilen hizmetlerin kalitesinin değerlendirilmesi için bir komisyon kurulması gerekmektedir. Cheng, Tsai \& Lin (2013), profesyonel olarak nitelikli öğrencileri yetiştirmek için temel faktörlerden birinin eğitimin kalitesi olduğunu belirterek, öğrenciler için belirlenen hedeflerin ve temel becerilerin kazanılmasının sadece yönetime değil, aynı zamanda öğrenme ortamına ve olanaklarına, öğrencinin beceri düzeyi ile eğitim danışmanlarına ve genel olarak, ne kadar iyi eğitim hizmetlerinin var olduğuna bağlı olduğunu belirtmektedir. Yani, program hedeflerine ulaşmak ve öğrencilerin temel becerilerini geliştirmek için hizmet kalitesinin önemli olduğunu vurgulamaktadır. Yükseköğretimde gerekli olan bu kalite unsurları, meslek yüksekokullarındaki eğitimin kalitesi bakımından da dikkate alınması gereken önemli faktörler olarak gösterilebilir.

Türkiye'de yükseköğretim kurumlarında eğitim, öğretim ve araştırma faaliyetleri ile idarî hizmetlerin değerlendirilmesi, kalitelerinin geliştirilmesi, kalite düzeylerinin onaylanması ve tanınması çalışmalarına katkı sağlamak amacıyla, Yükseköğretim Kurumlarında Akademik Değerlendirme ve Kalite Geliştirme Yönetmeliğinin (2006) yayınlanması önemli bir gelişmedir. Çünkü, bu düzenleme ile yükseköğretim kurumlarında akademik değerlendirme ve kalite geliştirmede ortak standartlar belirlenmiştir (YÖDEK, 2007). Ayrıca, yükseköğretim kurumlarında akreditasyona dayalı kalite çalışmalarını daha etkin yürütebilmek amacıyla, 2015 y1lında gerçekleştirilen ilk yasal düzenlemeler sonrasında, Kalite Güvencesi ve Kalite Kurulu Yönetmeliği (2018) yayınlanmıştır. Bu düzenlemeler ile yükseköğretim kurumlarında kalite kurulu oluşturulması ve kalite çalışmalarının daha sağlıklı planlanması ve yürütülmesi hedeflenmiştir.

Elmacı, Poyraz ve Çalık'a (1999, s.114) göre, meslek yüksekokullarında eğitimin kalitesini etkileyen bazı iç ve dış faktörler bulunmaktadır. Dış faktörler olarak, öğrenci özellikleri, öğretim elemanlarının nitelik ve niceliği, malî kaynaklar, altyap1, programlar, destek hizmetleri, yapısal düzenlemeler (ekonomik, nüfus ve sosyal), kurumsal mekanizmalar, politika ve stratejiler (mevzuat), kamu ve özel sektör ile mevzuat belirtilmektedir. Meslek yüksekokullarında eğitimin kalitesini etkileyen iç faktörler ise katı (kolay değiştirilemeyen) ve esnek (kolay değiştirilebilen) faktörler olarak iki kategoride belirtilmiştir. Katı faktörler olarak, fizikî ve akademik altyapı, sınav ve değerlendirme sistemi, eğitim teknolojisi, insan gücü ve akademik personeli geliştirme sıralanmaktadır. Esnek faktörler olarak da çalışma yöntemleri, yönetim biçimleri, tasarım, uygulama ve veri sistemleri gibi faktörler belirtilmektedir. Karasioğlu ve Duman (2011), meslek yüksekokullarında, eğitimin kalitesini etkileyen, teknolojik, ekonomik, yönetsel, öğretim elemanı ve öğrenci gibi faktörlerin bulunduğunu belirtmektedir. Meslek yüksekokulları da dahil olmak üzere, yükseköğretimde kalitenin sağlanabilmesi için, iyi bir şekilde planlanması ve etkili yönetimi büyük önem taşımaktadır.

Yükseköğretimde kalite yönetimi, eğitimin her aşamasında ve eğitimi etkileyen aşağıdaki tüm alanlarda sağlanmalıdır (Elmac1 vd., 1999, s.115-116):

1. Fizikî altyapı (bina, spor tesisleri, açık alan, .... vb.)

2. Akademik altyapı (laboratuvar, kütüphane, dokümantasyon, iletişim, bilgi işlem... vb.) 
3. Müfredat,

4. Sinav ve değerlendirme sistemi,

5. Akademik/idarî personel temin ve geliştirme, teşvik sistemi,

6. Araştırma ve yayınlar,

7. Kurumsal gelişme planı (stratejik planlama),

8. Üniversite-sanayi-toplum ilişkileri vb.

Alkan, Suiçmez, Aydınkal ve Şahin (2014), meslekî ve teknik ortaöğretim kurumlarından meslek yüksekokullarına sınavsız geçiş uygulamasının meslek yüksekokullarında eğitimin kalitesini olumsuz etkilediğini ifade etmektedirler. $\mathrm{Bu}$ uygulama ile öğrenci sayısı artmasına rağmen, altyapı, mekân, donanım ve öğretim elemanı ihtiyacının giderilemediği belirtilmektedir. Ancak, meslek yüksekokullarına sınavsız geçiş uygulaması 2017 yılından itibaren kaldırılmıştır. Tüzün-Arpacıoğlu, Can ve Aktaş (2019), meslek yüksekokullarına sınavsız geçiş uygulamasının kaldırılmasının olumlu bir gelişme olduğunu ve böylece öğrenci başarısının artacağı, mezunların istihdamının kolaylaşacağı, meslek yüksekokullarında eğitimin kalitesinin artacağını vurgulamaktadır. Saydan'ın (2008, s.44-46) da belirttiği gibi, yükseköğretim kurumlarında öğrenim gören öğrencilerin eğitimin kalitesi başta olmak üzere, sosyal, kültürel ve sportif etkinlikler ile fizikî alanların yeterliliğine yönelik beklentileri gün geçtikçe artmaktadır. Ayrıca, Can vd., (2017) meslek yüksekokullarında kampüs yeri, öğrenci yapısı, eğitim şekli, üniversite sanayi iş birliği, staj uygulaması, teknolojik altyap1, öğretim elemanı, mezunların istihdamı ile mezunların takip edilememesi gibi konularda sorunlar yaşandığını belirtmektedirler. Bu noktada, kaliteli eğitim hizmeti sunan ve mezunlarının istihdam edildiği üniversitelerin tercih edilme olasılığının daha yüksek olacağı belirtilmektedir. Erdoğan ve Uşak'a (2004) göre, yükseköğretimde öğretim elemanları, idarî personel, üniversite kampüsü ve olanakları, sosyo-kültürel etkenler ile öğrenci görüşlerine önem verilme düzeyi, öğrenci memnuniyetini etkileyen faktörlerdir. Şahin (2009) ise, yükseköğretimde hizmet kalitesini etkileyen temel faktörlerin öğretim elemanı, danışmanlık hizmetleri, yönetim, kaynaklar, teknolojik olanaklar ile ders programları olduğunu, öğrencilerin bu alanlara yönelik memnuniyet düzeylerinin düşük olduğunu ve öğrencilerin bu konuda önemli beklentileri bulunduğunu belirtmektedir. Bu yüzden, yükseköğretim kurumlarında, özellikle meslek yüksekokullarında kaliteyi etkileyen bu faktörlerin önemi dikkate alınmalıdır. Ancak, Günay ve Özer'e (2016) göre, Türkiye'de meslekî eğitim, yükseköğretim sisteminin genel zorluk ve sorunlarından etkilenmekle birlikte, meslek yüksekokulları arasında kalite farklılıkları bulunmamaktadır. Ayrıca, meslek yüksekokulları öğrenci kabul sistemi, altyapı yetersizliği, mezunlara yeterli bilgi ve beceri kazandırılamaması ile mezunların istihdamı gibi konularda önemli sorunlar yaşamaktadır. Son yıllarda Türkiye'de yükseköğretimde kalite konusunun ön planda olduğu ve Yükseköğretim Kurulunun kalite konusunda önemli girişimlerde bulunduğu ancak, yeterli olmadığı söylenebilir. $\mathrm{Bu}$ yüzden, bu araştırmanın bulgularının meslek yüksekokullarında kalitenin geliştirilmesi ve sürdürülmesinde önemli katkılar sağlayacağ düşünülmektedir.

Literatür incelemelerinde, meslek yüksekokullarında kalite konusuna ilişkin araştırmaların (Elmacı vd., 1999, Alkan vd., 2014; Ceylan ve Erbir, 2015; Günay ve Özer, 2016) sinırlı sayıda olduğu görülmektedir. Mevcut araştırmaların tamamına yakını ise, meslekî eğitimin belirli alanına yönelik olarak, nicel araştırma veya betimsel araştırma (Alkan, vd., 2014; Karasioğlu ve Duman, 2011; Elmacı vd., 1999, Türeli ve Aytar, 2014; Karacan ve Karacan, 2004; Öztürk ve Tataroğlu, 2017; Karahan ve Kuzu, 2014; Can vd. 2017; Öz, 2017) olarak yürütülmüştür. $\mathrm{Bu}$ araştırmanın diğer araştırmalardan en önemli farkı ve önemi, meslek yüksekokullarında kalitenin geliştirilmesine yönelik faktörlerin bir bütün olarak ele alınması, araştırmanın nitel araştırma yöntemi ile yürütülmesi ve verilerin içerik analizi ile değerlendirilmiş olmasıdır. Ayrıca, araştırmanın verilerinin yazılı olarak toplanması, daha fazla sayıda veri elde edilmesine olanak sağlamıştır. Böylece, bu alanda yürütülen nicel araştırmalardan farklı olarak, bu araştırmada daha kapsamlı veriler elde edilmiş ve alana daha çok katkı sağlanabileceği değerlendirilmektedir. $\mathrm{Bu}$ nedenlerle, bu araştırma büyük önem taşımaktadır.

$\mathrm{Bu}$ araştırmanın amacı, meslek yüksekokullarında kalitenin geliştirilmesine yönelik ihtiyaçları belirlemek ve alana yönelik öneriler geliştirebilmektir. Bu amaçla, "Meslek Yüksekokullarında kalitenin sağlanabilmesi için neler yapılabilir?” sorusuna yanıt aranmıştır.

\section{Yöntem}

Araştırmanın bu bölümünde, araştırmanın modeli, çalışma grubu, veri toplama arac1, verilerin toplanmas1, verilerin analizi ve araştırmanın sınırlılıkları başlıklarına yer verilmiştir.

\subsection{Araştırma Modeli}

Araştırmada nitel araştırma yöntemi kullanılmıștır. Nitel araştırma yöntemi, belli bir konu hakkında daha derinlemesine ve kapsamlı bilgi elde edilmesine olanak sağlamaktadır (Denzin \& Lincoln, 2005; Marshall \& Rossman, 2006; Singh, 2007; Patton, 2014). Nitel araştırmalar, her türlü gerçekliğin bireyler tarafından sosyal çevrenin etkileşimi yoluyla oluşturulduğu varsayımına dayanmaktadır (Merriam, 1998). Araştırma kapsamında olgu bilim (fenomenoloji) deseninden yararlanılmıştır. Bu desen, belirli konularda daha derinlemesine veri elde edilmesinde tercih edilmektedir. Yıldırım ve Şimşek'e (2006 s.72) göre, olgu bilim (fenomenoloji) deseni farkında olduğumuz ancak, derinlemesine ve ayrıntılı bir anlayışa sahip olmadığımız olgulara odaklanmaktadır. Olgu bilim araştırmaları nitel araştırmanın doğasına uygun olarak kesin ve genellenebilir sonuçlar ortaya koymayabilir. Ancak, bir olguyu daha iyi tanımamıza ve anlamamıza yardımcı olacak 
sonuçlar sağlayacak örnekler, açıklamalar ve yaşantılar ortaya koyabilir. Bu yönü ile hem bilimsel alanyazına, hem de uygulamaya önemli katkılar getirebilir (Yıldırım ve Şimşek, 2006, s.75). Bu araştırmada, meslek yüksekokullarında kalitenin sağlanabilmesi için ihtiyaçları belirlemek ve kalite için neler yapılması gerektiğine ilişkin daha derinlemesine veriler elde edebilmek için olgu bilim deseni tercih edilmiştir. Çünkü, meslek yüksekokullarında öğrenim gören öğrencilerin kalite ihtiyacına ilişkin daha kapsamlı bilgiler ve örnekler sunabilecekleri değerlendirilmiştir. Böylece, nitel araştırmada kullanılan olgu bilim deseninin meslek yüksekokullarında kalitenin sağlanabilmesi için nelere ihtiyaç duyulduğunun belirlenmesine, konunun daha iyi anlaşılmasına ve sorunların çözümüne yönelik uygulanabilir önerilerin geliştirilmesine yardımcı olacağı değerlendirilmiştir.

\section{2. Çalışma Grubu}

Araştırmanın çalışma grubu, 2017-2018 öğretim yılında Kırklareli Üniversitesi'ne bağlı yedi Meslek Yüksekokulunda (Babaeski, Lüleburgaz, Pınarhisar, Sağlık Hizmetleri, Sosyal Bilimler, Teknik Bilimler, Vize) öğrenim gören ve araştırmaya katılmayı gönüllü olarak kabul eden 120 öğrenciden oluşmaktadır. Araştırma, Kırklareli Üniversitesi'ne bağlı tüm meslek yüksekokullarında yürütülmüştür. Araştırmaya katılan öğrencilerin \%55'i (66 kişi) kadın, \%45'i (54 kişi) ise erkektir. Katılımcıların \%25'i (30 kişi) Babaeski, \%20'si (24 kişi) Sosyal Bilimler, \%15'i (18 kişi) Sağlık Hizmetleri, \%15'i (18 kişi) Lüleburgaz, \%10’u (12 kişi) Teknik Bilimler, \%10’u (12 kişi) Pınarhisar, \%5'i (6 kişi) ise Vize Meslek Yüksekokulu'nda olmak üzere, toplam 33 farklı programda öğrenim görmektedir. Yıldırım ve Şimşek’e (2006, s.74) göre, olgu bilim araştırmalarında veri kaynakları, araştırmanın odaklandığı olguyu yaşayan ve bu olguyu dişa vurabilecek veya yansitabilecek bireyler ya da gruplardır. Bu araştırmada da veri kaynağı olarak meslek yüksek okullarında öğrenim gören ve meslek yüksekokullarında kalite ihtiyacını belirleyerek, kalite için neler yapılması gerektiğine ilişkin veriler elde edebilmek için zengin veri kaynağına sahip olduğu düşünülen öğrenci görüşlerine başvurulmuştur.

\subsection{Veri Toplama Arac1}

Araştırmanın verileri bir açık uçlu sorudan oluşan anket formu aracılığıyla yazılı olarak toplanmıştır. Veri toplama aracı oluşturulmadan önce üç açık uçlu sorudan oluşan anket formu aracılığıyla 20 öğrencinin katılımı ile pilot uygulama gerçekleştirilmiş ve elde edilen veriler eğitim yönetimi alanındaki üç öğretim üyesinin görüşü alınarak değerlendirilmiştir. Görüşüne başvurulan eğitim yönetimi alanındaki üç öğretim üyesi, veri toplama aracının yapılandırılmış bir açık uçlu sorudan oluşmasını ve daha fazla veri elde edebilmek amacıyla, verilerin yazılı olarak toplanmasını önermişlerdir. Pilot araştırma verilerinin analizi ve uzman önerileri sonucunda, katılımcıların "Meslek Yüksekokullarında Eğitimin Kalitesinin Arttırılabilmesi için
Neler Yapılabilir? Önerileriniz Nelerdir?” sorusunu yazılı olarak yanıtlamaları istenmiştir. Ayrıca, demografik veriler kapsamında, öğrencilerin cinsiyeti, öğrenim gördükleri meslek yüksekokulu ve program ile ilgili sorulara yer verilmiştir.

\subsection{Verilerin Toplanmas1}

Veriler toplanmadan önce, Üniversite yönetiminden yasal izinler alınmış ve araştırma gönüllü ögrencilerin katılımı ile gerçekleştirilmiştir. Araştırmanın verileri katılımcılardan yazılı olarak toplanmıştır. Verilerin toplanması sürecinde, araştırmanın yürütüldügü meslek yüksekokullarında görevli yönetici ve öğretim elemanlarından destek alınmış ve araştırma hakkında öğrencilere bilgilendirmede bulunulmuştur. Verilerin toplanması süreci ortalama 20 dakika ile 40 dakika arasında değişkenlik göstermiştir. Katılımcıların araştırma sorusuna derinlemesine ve daha kapsamlı yanıt vermelerini sağlamak amacıyla süre ve ortam bakımından gerekli olanaklar sağlanmıştır.

\subsection{Verilerin Analizi}

Araştırmanın verileri, nitel araştırma kapsamında tema ve alt temalara ayrılarak içerik analizi ile değerlendirilmiştir. Yıldırım ve Şimşek'e (2006, s.75) göre, olgu bilim araştırmalarında veri analizi, yaşantıları ve anlamları ortaya çıkarmaya yöneliktir. Bu amaçla yapılan içerik analizinde verinin kavramsallaştırılması ve olguyu tanımlayabilecek temaların ortaya çıkarılması çabası vardır. Araştırmanın verileri altı tema altında içerik analizi yardımıyla değerlendirilmiştir. Yıldırım ve Şimşek’e (2006, s.89) göre, içerik analizi, nitel araştırma verilerinin analizinde kullanılan en temel yöntemlerden biridir. İçerik analizi, elde edilen verilerin daha yakından incelenmesini ve bu verileri açıklayan kavram, tema ve alt temalara ulaşılmasını gerektirmektedir. Araştırma verilerinin analizi sonucu ortaya çıkan alt temalar şunlardır: 1-öğrenciler, 2-öğretim elemanlar1, 3-öğretim süreci, 4- olanaklar, 5-yönetim, 6etkinlikler. Araştırmanın güvenirliğini sağlamak amacıyla, katılımcı görüşlerinden doğrudan alıntılar yapılarak katılımcı numaraları (K1, K2, K3...) şeklinde belirtilmiş ve bulgular bölümünde sunulmuştur. Creswell'in (2015)'de belirttiği gibi, nitel araştırmalarda bulguların yorum yapılmadan doğrudan sunulması araştırmanın güvenirliğine katkı sağlamaktadır.

\subsection{Araştırmanın Sınırlılıkları}

$\mathrm{Bu}$ araştırmanın meslek yüksekokullarında yürütülmesi, ayrıca verilerin yapılandırılmış bir açık uçlu soru ile yazılı olarak toplanması, sınırlılık olarak belirtilebilir.

\section{Bulgular}

Araştırma verilerinin analizi sonucunda, öğrenci görüşlerine göre ortaya çıkan temalara ve alt temalara bağlı olarak, meslek yüksekokullarında kalitenin geliştirilmesine yönelik ihtiyaçlar ve öneriler Tablo.1'de sunulmuştur. 
Tablo 1. Meslek Yüksekokullarında Kalitenin Geliştirilmesine Yönelik İhtiyaçlar

\begin{tabular}{|c|c|c|c|}
\hline Tema & Alt Tema & Kodlar & Kişi Sayısı (N) \\
\hline \multirow{6}{*}{ 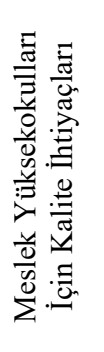 } & Olanaklar & Fiziksel, Teknolojik, Derslik, Kütüphane, Laboratuvar, Atölye, Kampüs. & 73 \\
\hline & Öğretim Elemanları & İletişim, Unvan, Yeterlik, Yöntem, Eşitlik. & 64 \\
\hline & Öğretim Süreci & $\begin{array}{l}\text { Uygulama, Seminer, Gezi, Laboratuvar, Yabancı Dil. } \\
\text { Ölçme ve Değerlendirme, Bilimsel Yöntemler. }\end{array}$ & 56 \\
\hline & Etkinlikler & Etkinlik, Bilimsel, Sosyal, Sportif, Eğlence, Yarışma, İşbirliği. & 52 \\
\hline & Yönetim & İletişim, Bütçe, Yönetim Biçimi, Planlama, Disiplin. & 47 \\
\hline & Öğrenciler & Yurtdışı, Değer, İlgi, Olanak, Görüş. & 38 \\
\hline
\end{tabular}

Tablo 1.’de görüldüğü gibi, meslek yüksekokullarında öğrenim gören öğrencilerin "Meslek Yüksekokullarında Kalite İhtiyaçları" temasına bağlı altı alt tema yer almaktadır. Ayrıca, bu alt temalara bağlı kodlar sunulmuştur. Tablo 1.'de görüldüğü gibi, öğrenciler en çok "olanaklar" alt temasına ilişkin görüş belirtmişlerdir (73 kişi). Öğrenciler sırasıyla "öğretim elemanları" alt teması (64 kişi), "öğretim süreci” alt teması (56 kişi), "etkinlikler" alt teması (52 kişi), "yönetim" alt teması (47 kişi) ve "öğrenciler” alt temasına (38 kişi) yönelik görüş belirtmişlerdir. Katılımcıların görüşlerinin demografik veriler olan cinsiyet, öğrenim gördükleri meslek yüksekokulu ve programa göre farklllık göstermediği ve görüşlerin genel olarak birbirine benzer olduğu sonucuna ulaşılmıştır.

Araştırma bulgularına göre, öğrencilerin “olanaklar” alt temasına ilişkin görüşleri incelendiğinde; meslek yüksekokullarında fiziksel ve teknolojik olarak derslik, araçgereç, internet alt yapısı, kütüphane, laboratuvar ve atölyelerin sağlıklı eğitim yapılacak şekilde düzenlenmesi ve uygun ortamların sağlanması, meslek yüksekokullarının merkezî kampüslerde yer alan her türlü olanağa sahip olması gerektiği belirtilmektedir. Bu konu ile ilgili bazı katılımcıların görüşleri şu şekilde belirtilmiştir:

"Internet altyapısının iyileştirilmesi gereklidir. Kullanılan aletler ve araç gereçler yenilenmesi lazım .... Derslik, atölye ve laboratuvarlar kaliteli değil, üstelik fazlası ile malzeme eksiği olduğunu düşünüyorum..."(K98).

"Her okulda kütüphanelerin olması çok önemli, bu yüzden kütüphanelere önem verilip geliştirilmelidir. Kayalı'da (Merkez Kampüste) olan A'dan Z'ye her şeyin MYO'da da olması gerekli. Amfi, sıralar, kafeler, kütüphaneler buraya da yapılmall, binalara özen gösterilmelidir” (K24).

"Meslekî atölyelerin çoğaltılması ve geliştirilmesi büyük ölçüde başarı kazandırır. Meslek atölyelerinin daha gelişmiş olması eğitimin kalitesini yeterince arttırır ve öğrencilere yeterli katkıy sağlar. Okulumuzda medya bölümü var ancak bir atölyesi yok. Yapılmasl gerekli" (K56).

"Medya ve iletişim bölümü için çok büyük ekipman eksiği var. Bunların karşılanması ve bölümün uzman öğretim görevlilerinden ders almak temennimdir. ......... MYO'da medya ve iletişim dersi için ekipman eksikliğinin giderilip, teorik bilgileri uygulayabilecek bir ortam oluşturulmasını rica ederim" (K17).

"Öğrencilerin mağdur edilmemesi ve alanlarında nitelikli çalışanlar olabilmesi için her programın atölye, laboratuvar vb. teknik ekipmanlarının tam ve kullanışl olması gerekir. Daha geniş bir uygulama alanı sunulabilir. Her şeyin ders olduğu bir ortam herkesi sıkar, bu nedenle aktivite ve uygulama alanlarının olması, öğrencinin daha renkli bir ĕgitim almasını să̆lar” (K107).

"Küçük okullarda bahçe düzenlenmesi ve bina içerisinde yapılabilecek çok fazla şey var ama, var olan alanlar otlak gibi gereksiz kullanıma birakllyyor. Sinıflara havalandırma koyulmall (klima). Teknolojik aletler fazlalaştırllmalı. Kütüphane ve çalışma sınıfları yapılmalı. Mesleklere yönelik derslik, atölye ve laboratuvar geliştirilmeli. Derslikler, laboratuvarlar yetersizdir, bu konuda çalışma yapılabilir (K85).

"Atölye, laboratuvar ortamlarl ile kültür ve sanat etkinliklerinin artırılması. Kütüphane yapılmal, okulun içi daha temiz ve üniversite eğitimi yapabilecek düzeyde olmall. Okulun bir rehber danışmanı olmall, sosyal aktiviteler olmalı ve ögrenciler teşvik edilmeli. Okul ana merkeze taşınmall, derslerin dişında Ingilizce kurslarl olmall. Okulun içi modernleşmeli, okul sosyal sorumluluk projeleri için teşvik edilmeli” (K43).

"Öncelikle teknolojiden ĕgitim ve ögretim açısından yararlanılması gerekir. Kültür açısından öğrencilere daha fazla olanak săglanmalıdır. Öğrencilerin yararlanmaları için her üniversitede bir kütüphane ve boş zamanlar için dinlenme yerleri kurulmalıdır... MYO binalarının onarımı, kütüphane eksiğinin giderilmesi, spor salonu, kantin gibi sosyal alanların arttırlabilmesiyle ögrencilerin okulu sevme oranları daha çok gelişebilir" (K29).

Araştırma bulgularına göre, öğrencilerin "öğretim elemanları" alt temasına bağlı görüşleri incelendiğinde, genel olarak öğretim elemanlarının yeterliklerinin arttırılması, öğrenci ile sağlıklı iletişim kurmaları, öğretim üyelerinin (Doç. Dr. ve Prof. Dr. unvanlı) ders vermelerinin sağlanması, derslerde öğrencilerin katılımını sağlayan yöntemler kullanmaları ve tüm öğrencilere eşit davranmaları önerilmektedir. $\mathrm{Bu}$ konu ile ilgili bazı katılımcıların görüşleri şu şekilde belirtilmiştir:

“Öğretmenlerin ögrencilerle sağlıklı iletişim kurması ve kin beslememesi gerekli. Dersleri daha sağlıklı anlatmal, gerekirse 10 defa aynı konuyu anlatmal, ögrenci olan biziz, ögrretmenlerin görevi de anlatmak, ĕger ögrenemezsek burada olmamızın bir anlamı kalmaz" (K23).

“Öğretim görevlilerinin bazllarının sevdikleri ögrencileri korumamaları ve onlara ayricalık yapmamaları gerekir", (K51). 
"Öğrencilerle daha çok ilgilenen öğretim elemanlarl ve gerçek branşında ĕ̆itim almış hocaların doğru ve verimli eğitim vermesi kalite ve başarıyı arttırır” (K99).

"Ĕgitim kalitesinin arttırılması için daha iyi ĕgitim şartları sunulmal ve alanında daha iyi ögretim görevlileri görevlendirilmelidir” (119).

“Öğretim görevlileri alanı olmayan dallardaki dersleri vermemeli, ögrenme açısından daha iyi olur” (27).

"Öğretim görevlilerinin yeterli bilgiye sahip olmadı̆̆ını ve hatta iyi ögretemediğini düşünüyorum. Bu konudaki görüşlerimiz artık dikkate alınmalıdır.... Öğretim elemanları ders anlatırken daha fazla bilgilendirmede bulunmalıdır. Ögrretim görevlilerinin ders anlatırken küçümser tavırlar yapmamast iyi olur" (K17).

“Öğrencilerle daha sağlam iletişim kurulabilir, onları ciddiye aldığıınız en azından belirtebilirsiniz. Yaptığ hatalarda azarlayarak değil, yanında olarak destek olabilirsiniz. Çoğu hocada bunun eksik olduğunu düşünüyorum. Öğretim elemanlarının öğrencilere daha fazla empati ile yaklaşması ĕgitime her açıdan katkıda bulunacaktır. Öğretim elemanları ile ögrenci arasındaki ilişkiler daha iyi olmalıdır" (K21).

"Bu okullardaki öğretim elemanlarının daha kaliteli ve daha fazla Doçent ve Prof. unvanl ögretim elemanlarının bulunmasl, daha düzenli ve daha iyi bir eğitim ve bununla beraber başarlların gelmesi. Üniversitenin kalite bakımından daha iyi bir yerde bulunmasl gerekir” (K28).

"Emekliliği gelmiş ögretim görevlilerinin yerine daha genç dinamik öğretim görevlilerinin gelmesi okulumuzda ki kaliteyi arttırır. Bazı kalitesiz hocaların gitmesi, daha kaliteli hocalar gelmesi daha iyi olur" (K55).

“Öğretim elemanlarının öğrencilere daha fazla sorumluluk ve daha fazla araştırma vererek öğrencileri derse ve sürece daha fazla adapte etmeleri kalite açısından oldukça faydalı olacaktır" (K4).

“Öğretim görevlilerinin öğrencilerle daha çok iletişim halinde olması lazım. Öğrencilerin morallerinin yüksek tutulması, ögrencileri dolayl yoldan pozitif şekilde etkileyecektir. Ögretim görevlileri ögrencilere bilgiyi daha çok ĕglenceli ve güzel bir anlatımla ögretebilir. Öğretim görevlilerine daha hızlı ve anlaşılabilir konuşmasının ögretilmesi gerekir” (K14).

"Kalite, ögrretmen ve ögrrencide biter. Öğretici ne kadar iyi ders anlatıp ögrenci de iyi dinlerse daha kaliteli olur. Dersin işlenmesinde kullanılan teknik geliştirilebilir (örneğin hocaların slaytı okuyarak ders anlatması yerine kendinin anlatması). Öğretim görevlilerinin veriyor olmakta bulunduğu dersleri daha önce de vermiş olması gerektiği kanaatindeyim...” (K19).

Araştırma bulgularına göre, katılımcıların “öğretim süreci” alt temasına ilişkin görüşleri incelendiğinde, uygulamalı eğitim, öğrencilere yönelik değişik seminerler, bilimsel etkinlikler ve geziler ile yabancı dil eğitimine ağırlık verilmesi, derslerde farklı yöntem ve teknikler ile öğrenci başarısının değerlendirilmesinde alternatif yöntemlerin kullanılması gerektiği önerilmektedir. Bu konu ile ilgili bazı katılımcıların görüşleri şu şekilde belirtilmiştir:

"Bilimsel toplantılar düzenlenmeli, ögrenci öğretmen ilişkisi arttırlmall, bireysel öğrenme olanakları arttırllmall, kütüphaneler gelişstirilmeli, ögrencilere iş olană̆ sağlanmalı, eğitim kurallarına uyulmalı” (K118).

"Derslerin yanı sıra çeşitli seminerler ve uygulamal derslere ağırlık verilmeli, çünkü, uygulamalı dersler ile kâğlt üzerinde ögrrendiğimiz bilgileri görsel olarak görmek istiyorum. Ayrıca, ögrencilerin okula ve derslere devamın arttırmak için motivasyon arttırıcı programların olması gerekli” (K38).

"Uygulamalı derslerin arttırılması gerekiyor. $\dot{I}_{S}$ ortamlarının nasıl ilerlediği, iş akışının nasıl olduğu ögrencilere gösterilmeli, tecrübe kazandirılmalıdır.

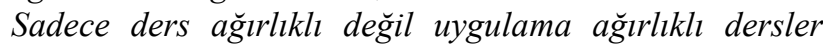
işlenirse daha fazla kaliteli olur" (K73).

"Kitaplardaki bilgilerden çok, meslekî anlamda bilgi verilmelidir. Meslek yüksekokulu adı üstünde, meslek öğretme amaçlı ĕgitimlerin daha çok olması gerekir. Farklı bölümler, eğitimi eğlenceli hale getirerek işlemelidir. Ayrıca, her ögrenilen bilginin, laboratuvar eşliğinde pekişmesi să̆lanmal, Ingilizce derslerinin ders saatleri arttırllmall ve daha ileri düzeyde ögretilmelidir" (K5).

“Önlisans mezunlarının lisans programlarına geçmesi için yapılan sinav zor olmamalıdır. Sinav sistemlerinde değişiklik yapllabilir. Vize ve final olarak 2 sinava tabi olduğumuz için sadece ezber sistemi var, böylece eğitimde bir kalite yakalayamayız. Bu konuda değişiklik olabilir. Ders saatlerinde değişiklik olabilir" (K37).

“A eğitime ăğlılk verilmelidir. Anatomi ve Fizyoloji dersini uygulamalı olarak yapmamı daha kaliteli bir ĕgitim almamızı sağlar. Dersleri tamamlamak adına daha fazla görsel araç olmalıdır. Dersler, deney, görsel araç vs. ile desteklenmeli. Dersler değişik yöntemler kullanılarak zevkli hale getirilmelidir. Bu sayede, derse katılim ve başarı olasılı̆̆l yükselecektir” (K41).

“Öğretim görevlisi sayısı arttırllmall. Ders saati uzatılmalı. Devamsızlı sinırı kaldırlmalıdır. Ders esnasında günlük hayattaki olaylar hakkında bilgi ve örnekler verilerek ilerlenmesi daha verimli olacaktır. Kültür ve sanat alanındaki etkinliklere daha çok yer verilmesi gerekir” (K42).

"50 dakika boyunca ders yerine, akılda kalıcı şeyler yapılabilir. Merkez kampüsteki gibi aktiviteler yapılmalı. Ders sayısı azaltılmalı. Staja yollanmalı bölümüyle ilgili haftada bir gün, să̆llk alanında olduğu gibi. Okuduğumuz bölümle alakalı olarak pratik yapabileceğimiz alanlar olmall, bize iş hayatında fayda sağlayacak bilgilerin verilmesi ve pratik yapllmasi...Derslerin uygulamal ĕgitim niteliğinde olması, iş bazında olması gerekli", (K65).

Araştırma bulgularına göre, katılımcıların "etkinlikler” alt temasına ilişkin görüşleri incelendiğinde, meslek yüksekokullarında bilimsel, sosyal, sportif ve kültürel etkinliklere daha çok önem verilmesi, öğrencilerin ders dişı zamanlarını daha iyi geçirebilmeleri için aktiviteler, eğlenceler düzenlenmesi, farklı kurum ve birimlerle daha çok iş birliği yapılması gerektiği belirtilmiştir.

"Sosyal aktivitelerin kampüs içinde arttırllmast, yeni bölüm ve binaların eklenmesi, kütüphane- çalışma alanı 
için ayr bir bina yapılması gereklidir. Sosyal alanların ve spor alanlarının arttırılması kaliteyi arttırır. Kütüphanenin geliştirilmesi, sosyal ve kültürel etkinliklerin düzenlenmesi, sanatsal etkinliklere özen gösterilmesi, sadece ders alanında kaliteyi arttırmak yerine, yapılacak etkinliklere özen gösterilmelidir. 4 yıllık bölümlerde olduğu gibi aktiviteler arttırılıp ögrenciler okula daha bağlı hale getirilebilir”' (K91).

"Meslek yüksekokulları, genelde küçük ilçelerde olduğu için sosyal olanaklar ders veriminde artışa neden olur ve ögrenci okulun bulunduğu yerden sikılmaz ve bu da okula gelen ögrenci sayısını ve mezun sayısını arttırır. Öğrencinin okuduğu bölüm ile ilgili aktiviteler yapılabilir. Öğrenciyi kazanmak için sosyal aktiviteler yapılabilir. Bu amaçla, ögrencilerin spor faaliyetlerini yerine getirebilecekleri bir spor salonu yaptırlabilir" (K34).

"Sadece ders ă̆ırlıklı de ğil sosyal olarak çeşitli olanaklar sunulması, ögrencilerin derslerden sonra rahatlaması derse hazır gelmesini sağlayacaktır. (Halı saha gibi.) Okulumuzda hiç etkinlik yapılmıyor. Kantinimiz sene başından beri hizmete kapal. Eğitim kalitesi için önce yaşam kalitesi sağlanmall. Okullarda spor etkinliklerine önem verilmeli. Sadece eğitim değil, çevre ve yaşam koşulları da gözden geçirilmeli. Geziler, sosyal etkinlikler daha sik düzenlenmelidir” (K78).

"Sosyal aktivitelerin arttırılarak daha fazla seminer ve çeşitli programlar düzenlenebilir. Kampüse sosyal aktiviteler yapılması. Daha iyi bir kütüphane ve kampüs içerisinde ögrencilerin vakit geçirebileceği kafeler. Kayalı (merkez kampüs) kampüsünde olduğu gibi. Öğrencilerle iyi iletişim, daha fazla sportif etkinlik, üniversiteler arası yarışmalar gibi" (K51).

Araştırma bulgularına göre, katılımcıların "yönetim" alt temasına ilişkin görüşleri incelendiğinde, öğrencilerle olumlu ve sürekli bir iletişim sağlanması, okulun ihtiyaçlarının giderilmesi için yeterli miktarda bütçe sağlanması, yönetimin her konuya daha duyarlı davranması ve öğrenci ihtiyaç ve beklentilerini esas alması, eğitim öğretim faaliyetleri ile fiziksel mekânın iyi bir şekilde planlanması, disipline önem verilmesi gerektiği vurgulanmaktadır. Bu konu ile ilgili bazı katılımcıların görüşleri şu şekildedir:

"Öğrencilerle daha fazla iletişim halinde olunması. Öğrenci işlerinin insanlarla diyalog kurma konusunda ĕgitimli olmalı ve her ögrenciye saygl gösterilmelidir. Devlet yurdu olmalıdır. Üniversitemizin eğitim kalitesini arttırmak için sosyal kaynakların arttırılması ve ögrenci bütçesi düşünülerek ortam sağlanması gerekir. Derslik, atölye vb. mekânlarda bakımların yapılması gerekir" (K30).

Bütün kampüslerin birleştirilerek öğrencilerin bilgi alışverişinin sağlanması. Okullar daha merkezi yerlere yapılmall, Faaliyetler daha fazla olmalıdır. Okula kampüs havası verilmelidir. Ĕ̆itim aldı̆̆ımız programlarla ilgili daha fazla olanak sağlanabilir. Yapllacak olan faaliyetler, sosyal çalışmalar, eğitim olanakları, araçlar ve gereçler eğitimin kalitesini arttırabilir. Daha fazla ögrencinin memnun olmasını ve daha seçkin bir üniversite olmayı etkileyebilir. MYO merkez kampüse taşınmal, içerik müfredatlar işyerlerinde çalışllabilecek şekilde düzenlenmelidir. Teoriden çok pratik önemlidir" (K52).

"Ders saatleri düşürülebilir. Eğlence olanakları arttırllabilir. Sınıflara klima taktırlabilir. Ders alanlarında uzmanlaşmış ögretmenler getirilebilir. Uygulamalı derslerin yapıldığ yerlerin daha yeterli ve bakıml olması sağlanabilir. Üniversitenin kırsal kesimlerde bulunması öğrencilerin kendilerini yeterince gösterememesi sorunudur. Aktivitelerde kisıtlı kalınıyor. Öğrencinin boş zamanlarında sosyal olabileceği büyük şehir veya büyük ilçelere üniversitenin kurulması daha iyi olur” (K41)

"Meslek yüksekokullarında özen biraz arttırlmalı ve imkân verilmeli. $\dot{I}_{s ̧}$ olanăg săglanmalı. Meslek yüksekokullarına katılım arttırılmalı. Rektörlük MYO’lara yeterli desteği vermelidir. Üniversite demokratik ortam içerisinde ögrenci ilişkisi bakımından ortak ve sabit disiplin düzeni ile değerlendirilmelidir. Öğrencilere özel danışmanlık hizmeti sağlanmalı, kültürel etkinlikler arttırlarak alanların çağdaş teknik temellerinin ögrenimleri kazandırılmalıdır” (K89).

"Sosyal etkinliklerin arttırlmasi, desteklenmesi ve sürdürülmesine olanak sağlanması. Teknoloji eksikliğinin giderilmesi. Laboratuvar ve kütüphane gibi ögrencilerin kendini geliştirebileceği yerlerin olması. Öğrencilerin dışa bă̆ımlılı̆̆ını yok edecek ortamların yaratılmast. Konferans sempozyum gibi uygulamaların Prof. ve Doç. düzeyinde hocalarla iletişim halinde olması ve istediği anda ulaşabilmesi. Bireysel olarak öğrenci sorunlarlyla ilgilenilmesi. Öğrenciyi ezberden uzak tutacak kalitede ders verilmesi. Öğrencilere burs verme olană̆ının olması", (K25).

“Okulumuzda kütüphanemiz yok, en büyük eksiklik budur. Kitap okumak, boş zamanımızı kütüphanede harcayacağımı ortam yaratılmasını istiyoruz. Vize ve final zamanlarında öğrencilerin ders çalışacağı ortam sunulmall, bu ortam kantin olmamall. Gereksiz çok fazla bölüm var, bu bölümleri açıp puan sınırını alt seviyeye indirip öğrenci doldurmak eğitimin kalitesini düşüreceğinden bu konuda daha dikkatli ve seçici olunmasl gerekebilir. Sosyal aktiviteler ile kültürel, sportif ve alt yapı zenginliğinin arttırılması gerekir” (K26).

"Kütüphane ana kampüste, ulaşım zor olduğu için bu yerleşkede de olmasını isterim. Temizlik yok denecek kadar az. Özellikle WC. Spor tesisi de uzak. Ulaşım ücretleri çok fazla ve bazen bu yüzden derslere gelemiyoruz, bir çözüm olmalı. Okulun daha bakıml, temiz ve güzel olmasi ögrencilerin önemsendiğini gösterir. Okulda daha fazla etkinlik alanı olması, derslerde yardımcı materyallerin kullanılmasi gerekir” (K59).

"Okulu lise yönetiyor gibi değil de, gerçekten üniversite yönetiyor gibi yönetmek gerekir. Ögrencilerin de üniversiteye geldiğini fark ettirmek gerekir. Okulun ögrencilere staj yerleri bulması sağlanabilir. İş olanakları, sosyal faaliyetler, elektronik aletlerin yenilenmesi vs." (K68).

Katılımcıların "öğrenciler” alt temasına bağlı olarak görüşleri incelendiğinde genel olarak, öğrencilerin ilgi, beklenti ve görüşlerinin esas alınması, öğrencilere değer verilmesi ve yurt dışı olanakları başta olmak üzere, daha iyi bir eğitim alabilmeleri için olanakların arttırılması önerilmektedir. $\mathrm{Bu}$ konu ile ilgili bazı katılımcıların görüşleri şu şekildedir:

"Anket yapılabilir, eğitimin kalitesinin sağlanması konusunda öğrenci görüşlerinden yararlanılabilir” (K84). 
“Öğrenciyi düşünüp ona göre hareket etmek başarıyı getirir, gerektiği durumlarda ögrencilere danışılmalıdır” (K23).

"Her öğrenciye aynı değerin verilmesi, okulun imkânlarının sonuna kadar kullandırllması gerekir. Daha fazla ögrencinin okulu tercih etmesi için aktiviteler yapılabilir" (K52).

"Öğrenci üniversiteyi benimsemeli, “bitse de gitsek” görüşünü ortadan kaldıracak çözümler üretilmelidir. Ö̆grenci üniversitenin ilim ve bilim yeri olduğunu unutmamalıdır", (K68).

"Meslek Yüksekokullarında özellikle meslekî alanlarla ilgili bilgilendirme için ögrencilere sunumlar yapılmalıdır. Ögrrencilerle ilgili daha fazla kulüp kurulmall. Sosyal projelere destek verilmelidir” (K61).

"Öğrencilerin istekleri dikkate alınarak eğitimle ilgili düzenlemelerin yapılması gerekir, Öğrencilerin derslere devamları să̆lanmalıdır. Öğrenciler kendilerine değer verildiğini hissetmek istiyor, üniversite ögrencisi olduğunu hissetmek istiyor...merkez kampüste yapllan etkinliklerin yapılmasını bekliyorlar..." (47).

"Öğrencilere ERASMUS gibi, yurtdışı proje olanakları sağlanmalıdır” (K63).

Araştırma bulgularına göre, araştırmaya katılan meslek yüksekokulu öğrencileri, meslek yüksekokullarında kalitenin sağlanabilmesi için sırasıyla "olanaklar, öğretim elemanları, öğretim süreci, etkinlikler, yönetim ve öğrenciler" alt temaları bağlamında, önemli çalışmalara gereksinim bulunduğunu belirtmişlerdir. Meslek yüksekokulu öğrencilerinin meslek yüksekokullarında daha kaliteli bir eğitim için bu alt temalara bağlı önemli önerilerde bulunduğu görülmektedir. Bu bulgular, meslek yüksekokullarının kalite ihtiyacı bulunduğunu ortaya koymaktadır.

\section{Sonuç ve Tartışma}

Araştırmadan elde edilen sonuçlara göre, araştırmaya katılan öğrenciler, meslek yüksekokullarında kalite ihtiyacının karşılanmasına yönelik kalite önerileri olarak "olanaklar" alt teması altında, fiziksel ve teknolojik olanaklar başta olmak üzere, kütüphane, laboratuvar, atölye ve kampüsün tüm fiziksel olanaklarının geliştirilmesi gerektiğini belirtmişlerdir. Benzer şekilde, değişik araştırma bulgularına (Türeli ve Aytar, 2014; Öztürk ve Tataroğlu, 2017; Cevher, 2015; Ceylan ve Erbir, 2015; Günay ve Özer, 2016; Can ve vd., 2017) göre, meslek yüksekokullarında fiziksel alan kapasitesi (kütüphane, derslik, kantin, sosyal mekân, kampüs yeri) başta olmak üzere, teknolojik araç-gereç ve donanım ile alt yapı bakımından bazı yetersizlikler bulunmaktadır. $\mathrm{Bu}$ amaçla, öncelikle üniversitelerin meslek yüksekokullarında bölüm veya program açmadan önce fizikî alt yapıyı oluşturmaları önerilmektedir. Bu yüzden, Yavuz ve Gülmez'e (2016) göre, özellikle yeni kurulan üniversiteler fiziksel yönden geliştirilmelidir. Çünkü, Altınok (2008), yükseköğretimde nitelikli eğitim için yeterli, düzenli ve huzur verici bir mekâna ve bu mekân ile uyumlu öğrenci sayısına ihtiyaç olduğunu, ayrıca yeterli düzeyde kütüphane ve laboratuvarlara ihtiyaç olduğunu belirtmektedir. Alkan vd. (2014) ise, araştırma sonuçları ile benzer şekilde, meslek yüksekokullarının üniversitelerin ana kampüslerinin dışında kurulmalarının öğrencilerin kampüs yaşantısının sunduğu pek çok sosyal/kültürel etkileşimden uzak kalmalarına, farklı bölümlerde öğrenim gören diğer öğrenci arkadaşlarıyla daha az etkileşime girmelerine neden olduğunu belirtmektedir. Araştırma sonuçlarını destekler nitelikte, Uçar ve Özerbaş (2013), meslek yüksekokullarında nitelikli bir eğitim hizmeti için derslik başına düşen öğrenci sayısının azaltılmasını ve uygulamalı eğitim için yeterli eğitim alt yapısının oluşturulması gerektiğini önermektedir. Görüldüğü gibi, araştırma sonuçları ile paralel olarak meslek yüksekokullarında kalitenin sağlanabilmesi için öncelikle, fiziksel ve teknolojik yönden alt yap1 hizmetlerinin tam olarak geliștirilmesi gerekmektedir. Araştırmaya katılan öğrencilerin yarıdan fazlasının (73 kişi), araştırmanın yürütüldüğü meslek yüksekokullarında "olanakların" yeterli olmadığını ve geliştirilmesi gerektiğini, merkez kampüste yer alan her türlü koşulların meslek yüksekokullarına da sunulmasını talep etmiş olmaları, meslek yüksekokullarında kalitenin sağlanabilmesinin temel koşulunun öncelikle fiziksel ve teknolojik koşulların sağlanması gerektiğini ortaya koymaktadır.

Araştırmadan elde edilen sonuçlara göre, araştırmaya katılan öğrenciler, meslek yüksekokullarında kalite ihtiyacının karşılanmasına yönelik kalite önerileri olarak "ögrretim elemanları" alt teması altında, yüksekokullarında görevli öğretim elemanlarının yeterliklerinin arttırılmasını, öğrencilerle iletişimlerinin geliştirilmesini ve öğretim elemanlarının derslerde farklı yöntem ve teknikler kullanmalarını istemektedir. Benzer şekilde, değişik araştırma sonuçlarına (Öztürk ve Tataroğlu, 2017; Uçar ve Özerbaş, 2013; Türeli ve Aytar, 2014; Ceylan ve Erbir, 2015; Günay ve Özer, 2016, Alkan vd., 2014) göre, meslek yüksekokullarında hizmet kalitesini belirleyen en önemli unsur olan öğretim elemanlarının yetersizliği ile alan dışından derslere girmesi, öğretim elemanlarının ders içi ve ders dışı akademik performansları, hizmet kalitesini düşürmekte ve öğrencilerde memnuniyetsizliğe neden olmaktadır. Meslek yüksekokullarında hizmet kalitesine yönelik, öğrenci beklentilerinin karşılanabilmesi için akademik personelin meslekî yeterliklerinin geliştirilmesi gerektiği belirtilmektedir. $\mathrm{Bu}$ sonuçlar, öğretim elemanlarının yeterliklerinin geliştirilmesi gerektiğine yönelik sonuçları desteklemektedir. Araştırmaya katılan öğrenciler, en az Doktora eğitimini tamamlamış öğretim üyelerinin (Dr.Öğr.Üyesi, Doç.Dr. ve Prof.Dr.) derslerine girmesini istemektedir. Ancak, 2019 verilerine (YÖK, 2019) göre, meslek yüksekokullarında ders verenlerin \%78'i öğretim görevlisidir. Bu sonuç, araştırmaya katılan öğrencilerin bu konudaki istek ve beklentilerini doğrulamaktadır. Yavuz ve Gülmez (2016) ise, yükseköğretim kurumlarında hizmet kalitesinin iyileştirilebilmesi için, öğrenci sayısı ile öğretim elemanı/üyesi arasında bir denge olması gerektiğini belirtmektedir. Ayrica, Can vd., (2017), meslek yüksekokullarından mezun olan öğrencilerin, eğitimleri esnasında yabancı dil, bilgisayar eğitimi ve iletişim ile ilgili dersler almak istediklerini, ayrıca öğrenci görüşlerinin önemsenmesinin faydalı olacağını belirtmişlerdir. Bu sonuçlar da, araştırmanın sonuçları ile benzerlikler taşımaktadır. Ancak, araştırma bulgularından farklı olarak, Öztürk ve Tataroğlu'na (2017) göre, meslek yüksekokullarında görevli öğretim elemanlarının öğrencilerle iletişimlerinden memnun oldukları belirtilmektedir. Meslek yüksekokullarında öğretim elemanlarından kaynaklanan sorunlarla karşılaşılması, öğretim elemanlarının yetiştirilmesi ve seçimi, ders 
yüklerinin yoğunluğu nedeniyle kendilerini geliştirme firsatlarının kısıtlı olması, alan dışı ders vermeleri gibi faktörlerle açıklanabilir. Bu sonuçlar, öğretim elemanlarının yeterliklerinin geliştirilmesi gerektiğini ortaya koymaktadır.

Araştırmadan elde edilen sonuçlara göre, araştırmaya katılan öğrenciler, meslek yüksekokullarında kalite ihtiyacının karşılanmasına yönelik kalite önerileri olarak "öğretim süreci” alt teması altında, öğretim sürecinde teorik eğitimden daha çok uygulamalı eğitime ağırlık verilmesi, derslerde alternatif yöntem ve tekniklerin kullanılması, öğrenci başarısının objektif yöntemlerle ölçülmesi ve değerlendirilmesi ile öğrencilerin bilimsel etkinliklere katılımlarının sağlanması gerektiğini ifade etmektedirler. Değişik araştırma sonuçlarına (Cevher, 2015; Erbir, 2015; Günay ve Özer, 2016; Can vd., 2017; Öz, 2017; Öztürk ve Tataroğlu, 2017; Aktaş, TüzünArpacioğlu ve Can, 2018; Güler, 2016; Kılıç, 2016) göre, meslek yüksekokullarında ezbere dayalı eğitim sistemi kaldırılmalıdır. Çünkü, öğrencilere yeterli düzeyde beceri kazandırılamamaktadır. Bu yüzden, uygulamalı programlara ağırlık verilmesi ve staj uygulama sürelerinin uzatılması önerilmektedir. Ayrıca, meslek yüksekokullarının iş sektörü ile iş birliğinin yetersiz olduğu belirtilerek, $3+1$ staj uygulamasının getirilmesi ve üniversite sanayi iş birliğinin geliştirilmesi gibi önerilerde bulunulmuştur. Bazı araştırma sonuçlarına göre ise, meslek yüksekokullarında staj uygulamalarına özel önem verilerek denetimi sağlanmalı (Karacan ve Karacan, 2004) ve öğrenci memnuniyetsizliği yaratabilecek tüm öğrenme süreçleri iyileştirilmelidir (Karahan ve Kuzu, 2014). Bu sonuçlar da, araştırma sonuçları ile paralel olarak, meslek yüksekokullarında uygulamalı eğitime daha fazla ihtiyaç olduğunu ortaya koymaktadır. Bu sonuçlara göre, üniversitelerin meslek yüksekokullarında staj uygulama sürelerini uzatmaları, iş sektörü ile iş birliği protokolleri yapmalarının gerekliliği ortaya çıkmaktadır. Araştırmanın çalışma grubunu oluşturan Kırklareli Üniversitesi'nde 2018-2019 öğretim y1lından itibaren meslek yüksekokullarındaki bazı programlarda pilot uygulama olarak staj sürelerinin uzatılması ve 3+1 staj uygulamasına geçilmesi, olumlu bir gelişme olarak değerlendirilebilir.

Araştırmadan elde edilen sonuçlara göre, araştırmaya katılan öğrenciler, meslek yüksekokullarında kalite ihtiyacının giderilmesi için kalite önerileri olarak "etkinlikler" alt teması altında, meslek yüksekokullarında sınıfta sadece öğretim yapılmaması gerektiğini ayrıca, ders dışında sosyal, sportif ve kültürel etkinliklere de önem verilmesi gerektiğini ifade etmişlerdir. Araştırmanın bu sonuçları ile paralel olarak, Türeli ve Aytar (2014), meslek yüksekokullarında öğrenim gören öğrencilerin sosyal imkânlarının arttırılmasını, Alkan ve vd. (2014) ise, öğrencilere yönelik sosyal, sportif ve kültürel etkinliklerin düzenlenmesi için projeler geliştirilmesi gerektiğini belirtmektedir. $\mathrm{Bu}$ sonuçlar da araştırma sonuçlarını destekler nitelikte, meslek yüksekokullarında akademik eğitimin yanında sosyal, sportif ve kültürel etkinliklerin de gerekli olduğunu doğrulamaktadır.

Araştırmadan elde edilen sonuçlara göre, araştırmaya katılan öğrenciler, meslek yüksekokullarında kalite ihtiyacının karşılanmasına yönelik kalite önerileri olarak "yönetim" alt teması altında, okul yönetiminin okulun ihtiyaçlarının giderilmesi için yeterli miktarda bütçe sağlamasını, öğrenci ihtiyaç ve beklentilerini esas almasını, her konuya daha duyarlı davranmasını, eğitim öğretim faaliyetleri ile fiziksel mekânın iyi bir şekilde planlanmasını istemektedir. Altınok'a (2008) göre, üniversite yöneticileri ile öğretim elemanlarının yetki ve sorumluluk sınırlarındaki belirsizlikler, fiziksel yapılaşma, eğitim, öğretim, inceleme ve araştırma gibi hizmetlerin aksamasına neden olabilir. Bu sonuçlara göre, meslek yüksekokullarında da eğitimin kalitesinin sağlanmasında, yöneticilerin ve öğretim elemanlarının yetki ve sorumluluklarının yasal olarak iyi bir şekilde belirlenmesi ve uygulamada buna dikkat edilmesinin faydalı olacağı belirtilebilir. Günay ve Özer (2016), meslek yüksekokullarında yönetsel bakımdan kalitenin arttırılmasına yönelik bazı önerileri şu şekilde sıralamaktadır: Ön lisans eğitiminde açı öğretimin payının düşürülmesi, eğitim istihdam ilişkisinin gözetilmesi, öğrenci yerleştirme sisteminin iyileştirilmesi, öğretim elemanı başına düşen öğrenci sayısının azaltılması, meslek yüksekokulu kalite derneklerinin kurulmasının teşvik edilmesi, eğitimin kalitesinin geliştirilmesine yönelik destekleyici projelere aktif katılım sağlanması, öğrencilerin destek programlarından yararlanmalarının sağlanması, lisans tamamlama olanaklarının iyileştirilmesi, meslek yüksekokullarında program açma kriterlerinin iyileştirilmesi ve etkinleştirilmesi. Ayrıca, meslek yüksekokullarında temel sorunlar arasında yer alan mezunların istihdamı ve takip edilmesi (Günay ve Özer, 2016; Can vd., 2017) gibi çalışmalarında yönetim tarafindan yerine getirilmesi gerekmektedir. Araştırmacının inceleme ve gözlemleri ile literatür incelemelerine göre, pek çok öğretim kademesinde olduğu gibi, meslek yüksekokullarında da yönetici olarak görevlendirmelerde genellikle vekalet yönteminin tercih edildiği, yönetici olarak görevlendirmelerde liyakat, uzmanlık ve yeterlilik gibi kriterlerin genellikle gözetilmediği görülmektedir. $\mathrm{Bu}$ durum, meslek yüksekokullarında yönetici, öğrenci, öğretim elemanı, personel, bütçe ve fiziksel alt yap1 kaynaklı sorunların ortaya çıkmasına neden olabilir veya bu faktörlere bağlı sorunların çözümünü güçleştirebilir. Araştırma sonucu, meslek yüksekokullarında yönetimin, kalitenin sağlanması, geliştirilmesi ve sürdürülmesi bakımından önemini ortaya koymaktadır. Aynı zamanda, YÖK'ün de, son y1llarda üzerinde çalıștığı, ancak yeterli olmadığı değerlendirilen meslek yüksekokullarında kalitenin sağlanmasına yönelik çalışmaların arttırılmasına ihtiyaç olduğu söylenebilir. Çünkü, Özer, Gür ve Küçükcan'a (2010, s.83) göre, alt yapısı olmayan, sanayi, hizmet, ticaret bölgelerine uzak ve/veya bağlantısı olmayan, yeterli öğretim elemanı bulunmayan çok sayıda MYO programı açılması, sorun olarak varlığını devam ettirmektedir.

Araştırmadan elde edilen sonuçlara göre, araştırmaya katılan öğrenciler, meslek yüksekokullarında kalite ihtiyacının karşılanmasına yönelik kalite önerileri olarak "öğrenciler" alt teması altında, öğrencilerin ilgi, beklenti ve görüşlerinin esas alınarak daha iyi bir eğitim alabilmeleri için yurt dışı eğitim gibi her türlü olanağın arttırılması, kendilerine değer verilmesi gerektiğini ifade etmişlerdir. Örneğin, Alkan vd. (2014), araştırma sonuçlarını destekler nitelikte, meslek yüksekokullarında öğrenim gören öğrencilerin yurt dışı değişim programları, sempozyumlar, fuarlar ve teknik geziler yapmaya özendirilmeleri gerektiğini belirtmektedirler. Bu konuda, araştırmaya katılan öğrencilerin önemli talep ve beklentilerinin bulunduğu görülmektedir. Türeli ve 
Aytar'ın (2014) meslek yüksekokullarında öğrenci beklentilerinin tam olarak karşılanamadığı ve öğrenciyi merkeze alan yaklaşımların izlenmesi gerektiği, Öztürk ve Tataroğlu'nun (2017, s.176) meslek yüksekokullarında öğrenim gören öğrencilerin hizmet kalitesine yönelik memnuniyetsizlikleri bulunduğu, Günay ve Özer'in (2016) ise, meslek yüksekokullarında öğrenci kabul sisteminin yeterli olmadığına ilişkin sonuçları, araştırma sonuçları ile benzerlik göstermektedir. Ancak, Ceylan ve Erbir'in (2015) araştırma sonuçlarında, bu araştırmadan farklı olarak, meslek yüksekokullarında karşılaşılan sorunların nedenleri arasında, sadece diploma almaya odaklanmış öğrencilerin varlığı ile ögrencilerin teknik ve sosyal alt yapılarının yeterli olmaması gösterilmektedir. Aktan'ın (2007) belirttiği gibi, yükseköğretim kurumlarının temel kalite göstergelerinden biri de öğrenci memnuniyetinin sağlanmasıdır. Bu yüzden, bazı araştırma sonuçlarında (Yıldız ve Ardıç, 1999; Baykal, Sökmen, Korkmaz ve Akgün, 2002) belirtildiği gibi, eğitim kurumlarında kalitenin sağlanabilmesi için öğrencilerin ilgi, ihtiyaç ve beklentileri belirlenmeli ve öğrencilere yönelik uygun öğrenme ortamları sağlanmalıdır. Çünkü, Şimşek, İslim ve Öztürk'ün (2019) de belirttiği gibi, öğrencilerin herhangi bir yükseköğretim kurumundan memnuniyet düzeyi, mevcut durumun yanında aynı zamanda, potansiyel öğrenci adaylarının kurumu tercih etme durumlarını da etkileyebilmektedir. $\mathrm{Bu}$ bağlamda, yükseköğretim kurumlarından biri olan meslek yüksekokullarında kalitenin sağlanabilmesi için öncelikle öğrenci memnuniyetinin sağlanmasına ihtiyaç bulunmaktadır.

Sonuç olarak, öğrenci görüşlerine göre meslek yüksekokullarında kaliteyi engelleyen pek çok sorun, çözüm beklemektedir. Araştırma sonucunda ortaya çıkan sorun alanları, meslek yüksekokullarında karşılaşılan farklı sorunlar ile ilişkili olarak birbirini etkileyebilmektedir. Örneğin; Alkan vd., (2014), meslek yüksekokullarında karşılaşılan temel sorunları, 2017 yılına kadar uygulanan sınavsız geçiş uygulaması, öğretim elemanı ihtiyacı, öğrencilerin bilinçli tercih yapmaması, bölüm ve programların plansız açılması, ders programlarının ihtiyaca uygun olmaması, staj uygulamalarının önemsenmemesi şeklinde sıralamaktadır. Bu tespitler, aynı zamanda meslek yüksekokullarındaki kaliteli eğitimin engelleri olarak gösterilebilir. Tüzün-Arpacıŏlu vd.,'nin (2019) araştırma sonuçlarına göre, meslek yüksekokullarına sınavsız geçiş uygulamasının kaldırılmış olması, öğrenci başarısını ve mezunların istihdamını arttıracak, ayrıca meslek yüksekokullarında kalitenin sağlanmasına önemli katkılar sağlayacaktır. Meslek yüksekokullarına öğrenci seçme sisteminin geliştirilmesi, istihdam alanı daralan programların kapatılması, nitelikli öğrencilerin tercih etmesini sağlayarak kaliteyi arttırabilir. Köksoy'a (1997) göre, üniversiteler kendi performanslarını ve niteliklerini ortaya çıkarabilmek için bazı göstergeleri esas almalıdır. $\mathrm{Bu}$ göstergeler, öğretim elemanı başına düşen öğrenci sayısı, öğretim elemanlarının niceliği ve niteliği, öğretim üyesi başına düşen yayın sayısı, öğrenci başına düşen kütüphane gideri, bilimsel araştırmaya verilen önem, yayın ve araştırma fonu miktarı, öğrenci-öğretim elemanı-yönetici ve işveren kuruluşlarının değerlendirmeleri şseklinde sıralanmaktadır. Bu göstergeler, araştırmanın sonuçları ile ilişkilendirildiğinde, meslek yüksekokullarında eğitimin kalitesinin sağlanması bakımından da gereklidir ve büyük önem taşımaktadır.

\section{Öneriler}

Araştırma sonucuna göre, öğrencilerin "olanaklar" alt temasında belirtilen görüşleri esas alındığında, meslek yüksekokullarında derslik, araç-gereç, internet alt yapısı, kütüphane, laboratuvar ve atölyelerin sağlıklı eğitim yapılacak şekilde düzenlenmesi ve uygun ortamların sağlanması, meslek yüksekokullarının merkezî yerlerde kurulmasının sağlanması gerekmektedir. Öğrencilerin merkez kampüste sunulan hizmetlerin kendilerine de sunulması beklentisi bulunmaktadır. $\mathrm{Bu}$ bağlamda, merkezî kampüslerde öğrencilere sunulan her türlü olanak meslek yüksekokulu ögrencilerine de sağlanmalıdır.

Araştırma sonucuna göre, katılımcıların "öğretim elemanları" alt temasına bağlı görüşleri doğrultusunda, öğrencilerin Doç. Dr., ve Prof. Dr. unvanlı öğretim üyelerinden ders/seminer alma beklentisi dikkate alındığında, meslek yüksekokullarına öğretim elemanı seçiminde niteliğe önem verilmesi, mevcut öğretim elemanlarının kendilerini geliştirmelerini sağlayacak teşvik sisteminin oluşturulması yararlı olabilir. Farklı birimlerde görevli Dr., Doç. Dr., ve Prof. Dr., unvanlı öğretim üyelerinin farklı meslek yüksekokullarında ders, seminer, söyleşi, etkinlik vb., şeklinde öğrencilere katkı sunmaları sağlanabilir. Öğretim elemanlarının ders yüklerinin sınırlandırılması, öğretim elemanı başına düşen öğrenci sayılarının azaltılarak araştırma yapmalarına olanak sağlanması, doktora ve üstü eğitim yapmalarına katkı sağlayabilir. Ayrıca, öğretim elemanlarının derslerde farklı yöntem ve teknik kullanarak ders anlatması ve öğrencilere eşit davranmaları yönündeki beklentileri dikkate alındığında, öğretim elemanlarına meslek içi eğitim sunulması, özellikle öğretim yöntem ve teknikleri ile iletişim vb. alanlarda yeterliklerinin sağlanması faydalı olabilir.

Araştırmaya katılan öğrencilerin "öğretim süreci” alt temasında belirtilen görüşleri esas alındığında, teorik derslerden daha çok uygulamalı eğitim ile ders sürecinde farklı ekinliklere yer verilmesi ve öğrenci başarısının objektif yöntemlerle değerlendirilmesi beklentisi olduğu görülmektedir. $\mathrm{Bu}$ sonuçlardan hareketle, akademik derslerin yoğunluğunun azaltılması ve meslek yüksekokullarında uygulamalı eğitime ağırlık verilmesi, iş sektörü ile kapsamlı anlaşmalar yapılması, 3+1 uygulamalı eğitime geçilerek tüm programlarda yaygınlaştırılması, bu kapsamda meslek yüksekokulları ile sektör eşleştirmelerinin yapılması önerilebilir. Uygulamalı eğitimin daha etkili yürütülebilmesi için öğretim elemanlarına danışmalık kapsamında ek ders ödemesi yapılması, bu konuya ilişkin standartların belirlenmesi önerilebilir. Ayrıca, meslekî eğitim kapsamında öğrencilere yönelik değişik seminerler, bilimsel etkinlikler ve geziler ile yabancı dil eğitimine ağırlık verilebilir. Öğrenme öğretme etkinliklerinde, alternatif yöntem ve teknikler kullanılabilir. Ayrıca, öğrenci başarısının değerlendirilmesinde, yazılı ve test türü sınavların yanında alternatif ölçme ve değerlendirme yöntemleri kullanılabilir.

Araştırma sonucuna göre, öğrencilerin “etkinlikler" temasında belirtilen görüşleri esas alındığında, meslek yüksekokullarında bilimsel, sosyal, sportif ve kültürel etkinliklere daha çok önem verilmesi, öğrencilerin ders diş1 zamanlarını daha iyi geçirebilmeleri için aktiviteler, 
eğlenceler düzenlenmesi, farklı kurum ve birimlerle daha çok iş birliği yapılması gerektiği önerilebilir.

Araştırma sonucuna göre, öğrencilerin "yönetim" alt temasında belirtilen görüşleri esas alındığında, yönetimin öğrencilerle iyi iletişim kurması, öğrenci sorunlarına duyarlı davranması, yönetimin öğrenci ihtiyaç ve beklentilerini esas alması önerilebilir. Meslek yüksekokullarına YÖK ve Üniversite yönetimleri tarafindan yeterli düzeyde bütçe olanağı sağlanması, kurumun fiziksel ve teknolojik ihtiyaçları başta olmak üzere, diğer ihtiyaçlarının giderilmesinde faydalı olabilir. Ayrıca, meslek yüksekokullarında yönetici olarak görevlendirilenlerin ilgili alanda deneyimli olmalarına, meslekî eğitim konusunda yeterliğe sahip olmalarına ve yönetim becerilerine uygun görevlendirme yapılmasına özen gösterilmelidir. Üniversite ve meslek yüksekokulu yönetimlerinin periyodik olarak öğrenci ve öğretim elemanı görüşlerine başvurarak, elde edilen görüşlere göre iyileştirici tedbirler almaları kalitenin sağlanmasında faydalı olabilir.

Araştırma sonucuna göre, katılımcıların "öğrenciler" alt temasına bağlı görüşleri de dikkate alınarak, meslek yüksekokullarında kalitenin sağlanabilmesi için öğrencilerin ilgi, beklenti ve görüşleri esas alınmalı, öğrencilere değer verilmeli ve yurt dışı olanakları başta olmak üzere, daha iyi bir eğitim alabilmeleri için olanaklar arttırılmalıdır. Öğrencilerin bireysel ve aldıkları eğitime ilişsin her türlü sorunlarının çözümüne yönelik rehberlik ve danışmanlık sistemi oluşturulmalıdır. Meslek yüksekokulu öğrencilerinin her türlü soru ve sorunlarının çözümünü kolaylaştırmak ve kalitenin sağlanmasına katkı sağlamak amacıyla e-rehberlik ve edanışmanlık uygulamaları geliştirilebilir. Ayrıca, öğrencilerin farklı birimleri ziyaret etmeleri sağlanabilir, kurum ziyaretleri ile öğrenci görüşlerinden yararlanılabilir.

\section{Kaynakça}

Aktan, C. C. (2007). Yükseköğretimde değişim: Global trendler ve yeni mekanizmalar. İzmir: Yaşar Üniversitesi Yayınları.

Aktaş, F. O., Tüzün-Arpacıŏlu, I. ve Can, E. (2018). Evaluation of internship practices in vocational colleges according to the views of academics (Kirklareli University case). Journal of Education and Training Studies. 6(11a), 60-68.

Alkan, R. M., Suiçmez, M., Aydınkal, M. ve Şahin, M. (2014). Meslek yüksekokullarındaki mevcut durum: Sorunlar ve bazı çözüm önerileri. Yükseköğretim ve Bilim Dergisi, 4(3), 133-140.

Altınok, V. (2008). Yükseköğretimde ilke ve yönelimler neler olmalı? Selçuk Üniversitesi Sosyal Bilimler Enstitüsü Dergisi, 19, 41-52.

Baykal, Ü., Sökmen, S., Korkmaz, Ş. ve Akgün, E. (2002). Öğrenci memnuniyeti ölçeği geliştirme çalışması. Hemşirelik Dergisi, 11(49), 23-32.

Can, E., Çiçek, H., Aktaş, F. O., Işıı, T., Kasap, B. B., Tezsezer, S. ve Tüzün-Arpacioğlu, I. (2017). Meslek yüksekokulu mezunlarının meslekî eğitimlerini değerlendirmeleri (Babaeski Meslek Yüksekokulu Örneği). Sosyal Bilimler Dergisi, 4(15), 220-247.

Cevher, E. (2015). Yükseköğretimde hizmet kalitesi ve kalite algısının belirlenmesine yönelik bir araştırma.
Uluslararası Sosyal Araştırmalar Dergisi, 8(39), 804-814.

Ceylan, H. ve Erbir, M. A. (2015). Meslek Yüksekokullarında kalite: Mevcut durum, sorunlar ve çözüm önerileri. Electronic Journal of Vocational Colleges. May 2015, 99-106.

Creswell, J. W. (2015). Nitel araşttrma yöntemleri (M. Bütün ve S. B. Demir, Trans. Eds.). Ankara: Siyasal.

Denzin, N. K. \& Lincoln, Y. S. (2005). The sage handbook of qualitative research. California: Sage Publications.

Elmacı, O., Poyraz, K. ve Çalık, M. (1999). Yükseköğretimde (meslek yüksekokullarında) kalite güvence sisteminin oluşturulmasına yönelik bir değerlendirme format önerisi. Dumlupınar Üniversitesi Sosyal Bilimler Dergisi, 1,111-137.

Elmas, M. (2012). Bologna süreci: Uygulama veya uygulayamama. Yüksekögrretim ve Bilim Dergisi, 2(3), 137-141.

Erdoğan, M. ve Uşak, M. (2004). Fen bilgisi öğretmen adayları memnuniyet ölçeğinin geliştirilmesi. Gazi Eğitim Fakültesi Dergisi, 25(2), 35-54.

Güler, Z. (2016). Meslek yüksekokullarında staj sorunsalı: David A.Kolb'un yaşantısal öğrenme kuramı kapsamında Eskişehir Meslek Yüksekokulu Büro Yönetimi ve Asistanlığı öğrencilerinin stajlarının değerlendirilmesi ve öneriler. 1.Ulusal Şişli Seтроzуити, Bildiri Özeti İçinde, 409-430.

Günay, D. ve Özer, M. (2016). Türkiye'de meslek yüksekokullarının 2000'li yıllardaki gelişimi ve mevcut zorluklar. Yükseköğretim ve Bilim Dergisi, 6(1), 1-12.

Jelena, L. (2010). Determinants of service quality in higher education, Interdisciplinary Management Research, 6, 631-647.

Karacan, S. ve Karacan, E. (2004). Meslek Yüksekokullarında (MYO) yapılan staj uygulamalarına ilişskin bir araştırma: Kalite ve verimlilik için iş yerleri-MYO iş birliğinin gereği. Kocaeli Üniversitesi Sosyal Bilimler Enstitüsü Dergisi, 8(2), 168-184.

Karahan, M. ve Kuzu, Ö.H. (2014). Yükseköğretimde kalite yönetim sistemi uygulamalarının toplam kalite yönetimi bağlamında değerlendirilmesi: Selçuk Üniversitesi Hadim ve Sarayönü Meslek Yüksekokulları Örneği. Atatürk Üniversitesi İktisadi ve İdari Bilimler Dergisi, 28(3), 23-41.

Karasioğlu, F. ve Duman, H. (2011). Meslek yüksekokullarında muhasebe eğitimi ve kalitesi üzerine bir not. Gaziantep Üniversitesi Sosyal Bilimler Dergisi, 10(1), 165-180.

Kılıç, S. (2016). Meslek yüksekokullarında uygulamalı alanlarda öğrenme yaklaşımlarının önemi ve öğrenen üzerindeki etkisinin saptanması. 1.Ulusal Şişli Sempozyumu, Bildiri Özeti İçinde, 205-220. 
Köksoy, M. (1997). Yüksekögrretimde kalite ve Türk Yüksekögretimi için öneriler. Ankara: Hacettepe Üniversitesi Mühendislik Fakültesi Vakfı Yayınları.

Marshall, C. \& Rossman, B. G. (2006). Designing qualitative research. California: Sage Publications.

Merriam, S. B. (1998). Qualitative research and case study applications in education. San Francisco, CA: Jossey-Bass.

Owlia, M. \& Aspinwall, E. (1996). A framework for the dimensions of quality in higher education. Quality Assurance in Education. 4(2), 12-20.

Öz, S. (2017). Türkiye'de eğitime dayalı istihdama yönelik meslek yüksekokullarının değerlendirilmesi. Istanbul Ticaret Üniversitesi Sosyal Bilimler Dergisi, 16(32), 161-178.

Özer, M., Gür, B. S. ve Küçükcan, T. (2010). Yükseköğretimde kalite güvencesi. Ankara: SETA Yayınları.

Öztürk, H. ve Tataroğlu, M. (2017). Meslek yüksekokullarında hizmet kalitesi: Mehmet Akif Ersoy Üniversitesi Sosyal Bilimler Meslek Yüksekokulu Örneği. Sosyal ve Beşerî Bilimler Araştırmaları Dergisi, 19(40), 162-179.

Patton, M. Q. (2014). Nitel araştırma ve değerlendirme yöntemleri. (M. Bütün \& S. B. Demir, Trans. Eds.) Ankara: Pegem Akademi.

Saydan, R. (2008). Üniversite öğrencilerinin öğretim elemanlarından beklentileri Yüzüncü Yıl Üniversitesi İİBF örneği. Gazi Üniversitesi İ̈BF Dergisi, 10(1), 63-79.

Singh, K. (2007). Quantitative social research methods. New Delhi: Sage Publications.

Şahin, A., E. (2009). Eğitim fakültesinde hizmet kalitesinin Eğitim Fakültesi Öğrenci Memnuniyet Ölçeği (EFÖMÖ) ile değerlendirilmesi. Hacettepe Üniversitesi Eğitim Fakültesi Dergisi, 37(37), 106-122.

Şimşek, H., İslim, Ö. F. ve Öztürk, N. (2019). Yükseköğretimde kalite arayışında bir gösterge olarak öğrenci memnuniyeti: Bir ölçek geliştirme çalışması. Trakya Ĕ̆itim Dergisi, 9(3), 380-395.
Tan, W. \& Simpson, K. (2008). Overseas educational experience of Chinese students an evaluation of service quality experience in New Zealand. Journal of Research in International Education, 7(1), 93-112.

Türeli, N. ve Aytar, O. (2014). Meslek yüksekokulu eğitiminde hizmet kalitesinin servqual yöntemi ile ölçümü: $\quad$ Karamanoğlu Mehmetbey Üniversitesi'nde bir uygulama. Akademik Bakış Dergisi, 43.

Tüzün-Arpacıŏlu, I., Can, E. ve Aktaş, F. O. (2019). Evaluating the open admission practice in vocational colleges (Kirklareli University case). Journal of Human Sciences, 16(1), 205-215.

Uçar, C. ve Özerbaş, M.A. (2013). Meslekî ve teknik eğitimin dünyadaki ve Türkiye'deki konumu. Ĕ̌itim ve Öğretim Araştırmalar Dergisi, 2(2), 242-253.

Yavuz, M. ve Gülmez, D. (2016). The assessment of service quality perception in higher education. Education and Science, 41(184), 251-265.

Yıldırım, A. ve Şimşek, H. (2006). Sosyal bilimlerde nitel araştırma yöntemleri. Ankara: Seçkin Yayıncılık

Yıldız, G. ve Ardıç, K. (1999). Eğitimde toplam kalite yönetimi. Bilgi Dergisi, 1,73-82.

YÖDEK. (2007). Yükseköğretim kurumlarında akademik değerlendirme ve kalite geliştirme rehberi. Ankara.

YÖK. (2019). Yükseköğretim istatistikleri. https://istatistik.yok.gov.tr/, web adresinden edinilmiştir.

Yükseköğretim Kurumlarında Akademik Değerlendirme ve Kalite Geliştirme Yönetmeliği. (2006). http://www.yodek.org.tr/?page=download\#, web adresinden edinilmiştir.

Yükseköğretim Kalite Güvencesi ve Yükseköğretim Kalite Kurulu Yönetmeliği. (2018). Resmî Gazete (Sayı: 30604), https://www.resmigazete.gov.tr/eskiler/2018/11/ 20181123-16.htm, web adresinden edinilmiştir. 